\title{
HIATUS IN PREHISTORIC CHRONOLOGY OF THE CIS-BAIKAL REGION, SIBERIA: PATTERN OR ARTIFACT?
}

\author{
Yaroslav V Kuzmin \\ Pacific Institute of Geography, Far Eastern Branch of the Russian Academy of Sciences, Radio St. 7, Vladivostok 690041, \\ Russia. Email: ykuzmin@tig.dvo.ru.

\begin{abstract}
The problem of a hiatus at about $6100-5300$ BP (about 4900-4200 cal BC) in the prehistoric chronology of the Cis-Baikal region in Siberia is discussed. Based on a critical evaluation of existing evidence, there was no discontinuity found in the cultural sequence between the Kitoi and Serovo/Glazkovo complexes of the Neolithic, and the proposed "hiatus" may be an artifact based on underestimation of solid data. Conventional ${ }^{14} \mathrm{C}$ dates are presented that were generated in the $1980 \mathrm{~s}$ to early 2000s for Cis-Baikal prehistoric burial grounds, and were later dated by the accelerator mass spectrometry (AMS).
\end{abstract}

\section{INTRODUCTION}

The Cis-Baikal (Pribaikalye, or pre-Baikal in Russian geographical sources; e.g. Suslov 1961) region of Siberia is one of the best-studied areas in northern Asia in terms of prehistoric archaeology. Surveys and excavations began there in the 1880s and continue until today (see summary of research done before the 1990s: Khlobystin 1996; Weber 1995). Since the 1970s, radiocarbon dating was actively used to study the chronology of the Cis-Baikal Neolithic and Bronze Age complexes, and first results were released in the late 1970s and 1980s (Khlobystin 1978; Konopatsky 1982; Mamonova and Sulerzhitsky 1989). Later on, a group of scholars led by A W Weber presented a model of prehistoric chronology and periodization in the Cis-Baikal (e.g. Weber 1995; Weber et al. $2002,2006)$ with an indication of a chronological "hiatus" between the Kitoi and Isakovo/Serovo Neolithic complexes (Table 1), which reflects, in their opinion, cultural discontinuity and significant depopulation of the region in the mid-Holocene. The intensive Russian-Canadian archaeological research in the Cis-Baikal since the 1990s (e.g. Lam 1994; ; Katzenberg and Weber 1999; Weber and McKenzie 2003; Weber et al. 1993, 1998, 2002, 2004, 2005) makes the release of original data of more importance for the international scholar community. Here, the issue of a "hiatus" in the CisBaikal archaeological chronology is discussed, along with the presentation of the first conventional ${ }^{14} \mathrm{C}$ dates for burial grounds later dated by Weber et al. (2006).

Table 1 Culture-history model of the prehistoric cultural complexes in Cis-Baikal, Siberia (after Weber et al. 2006).

\begin{tabular}{llll}
\hline Period & Culture/mortuary complex & ${ }^{14}$ C age BP & Calibrated age BC \\
\hline Late Mesolithic & Early Kitoi & $\sim 8000-7000$ & $\sim 6800-5800$ \\
Early Neolithic & Late Kitoi & $\sim 7000-6100$ & $\sim 5800-4900$ \\
Middle Neolithic & Hiatus & $\sim 6100-5300$ & $\sim 4900-4200$ \\
Late Neolithic & Early Isakovo/Serovo-Glazkovo & $\sim 5300-4800 / 4400$ & $\sim 4200-3400 / 3000$ \\
Bronze Age & Late Isakovo/Serovo-Glazkovo & $\sim 4800 / 4400-3300$ & $\sim 3400 / 3000-1000$ \\
\hline
\end{tabular}

\section{THE MID-HOLOCENE HIATUS ISSUE: EVIDENCE PRO AND CONTRA}

The major problematic point in the prehistoric chronology of the territory around Lake Baikal, in my opinion, is the existence of an apparent "hiatus" at about 6100-5300 BP (about 4900-4200 cal BC) (e.g. Weber et al. 2002:230, 2006:127; originally stated: Weber 1995:154). In addition to numerous ${ }^{14} \mathrm{C}$ dates from burial grounds (see summary: Weber et al. 2006), some other lines of evidence were used to argue in favor of this pattern. For example, food and demographic stresses and possible environmental impact might be responsible for the "loss of archaeological visibility" of the late Kitoi complex according to Weber et al. (2002:285-6). It was concluded that "...the discontinuity 
between the Kitoi and Serovo-Glazkovo cultures was a concrete event and not the result of archaeological invisibility" (Weber et al. 2002:290).

However, since the early 1980s several ${ }^{14} \mathrm{C}$ dates between $\sim 6040$ BP and $\sim 5430$ BP (Table 2) are known from the literature for the Cis-Baikal region (e.g. Michael 1992); these dates argue against the interpretation of a "hiatus." Upon examination of arguments in favor of a hiatus (Weber 1994, 1995; Weber et al. 2002), I found out that only ${ }^{14} \mathrm{C}$ dates from burials were accepted, while dates from some "habitation sites" were apparently not considered (e.g. Weber 1994:8, caption to Figure 3). Some other ${ }^{14} \mathrm{C}$ values run on human bone from the Semenovo I cemetery, $\sim 6040 \mathrm{BP}$, and Sarminskii Mys, 5500 BP (Table 2; Mamonova and Sulerzhitsky 1989:22; Goriunova 2003:19), can also be cited as examples of human presence occurring during the hiatus.

Table $2{ }^{14} \mathrm{C}$ dates from archaeological sites in the Cis-Baikal region, associated with the suggested hiatus in prehistoric cultural chronology.

\begin{tabular}{|c|c|c|c|c|}
\hline Site name, geographic location & $\begin{array}{l}{ }^{14} \mathrm{C} \text { date } \\
\text { uncalib. BP }\end{array}$ & Material dated & $\begin{array}{l}\text { Lab code } \\
\& \mathrm{nr} .\end{array}$ & Reference \\
\hline $\begin{array}{l}\text { Shamanskii Mys (cultural layer 1), } \\
\text { Ol'khon Island }\end{array}$ & $5990 \pm 40$ & charcoal & SOAN-845 & $\begin{array}{l}\text { Konopatsky } 1982 ; \\
\text { Orlova } 1995\end{array}$ \\
\hline $\begin{array}{l}\text { Shamanskii Mys (grave 3), } \\
\text { Ol'khon Island }\end{array}$ & $5720 \pm 50$ & wood & LE-1076 & Konopatsky 1982 \\
\hline $\begin{array}{l}\text { Sagan-Zaba (layer 3), } \\
\text { Ol'khon Island vicinity }\end{array}$ & $6000 \pm 40$ & animal bone & SOAN-1572 & $\begin{array}{l}\text { Orlova 1995; } \\
\text { Goriunova } 2003\end{array}$ \\
\hline Tudugu, Olkhon Island vicinity & $5875 \pm 50$ & animal bone & SOAN-1681 & $\begin{array}{l}\text { Konopatsky } 1982 \text {; } \\
\text { Orlova } 1995\end{array}$ \\
\hline $\begin{array}{l}\text { Ityrkhei (layer 6), } \\
\text { Ol'khon Island vicinity }\end{array}$ & $5700 \pm 200$ & animal bone & GIN-4881 & Goriunova 2003 \\
\hline $\begin{array}{l}\text { Ityrkhei (layer 5), } \\
\text { Ol'khon Island vicinity }\end{array}$ & $5680 \pm 60$ & soil from hearth ${ }^{b}$ & SOAN-3341 & $\begin{array}{l}\text { Orlova 1998; } \\
\text { Goriunova 2003; }\end{array}$ \\
\hline $\begin{array}{l}\text { Sarminskii Mys (grave } 11 \mathrm{~b})^{\mathrm{c}} \text {, } \\
\text { Ol'khon Island vicinity }\end{array}$ & $5500 \pm 400$ & human bone & GIN-5599 & Goriunova 2003 \\
\hline $\begin{array}{l}\text { Ulan-Khada (layer 10), } \\
\text { Ol'khon Island vicinity }\end{array}$ & $5495 \pm 125$ & soil from hearth ${ }^{\mathrm{b}}$ & SOAN-3336 & $\begin{array}{l}\text { Orlova 1998; } \\
\text { Goriunova } 2003\end{array}$ \\
\hline Semenovo (burial 6), Angara River & $6040 \pm 100$ & human bone & GIN-3878 & $\begin{array}{l}\text { Mamonova and } \\
\text { Sulerzhitsky } 1989\end{array}$ \\
\hline Gorely Les (layer 5a), Angara River & $5430 \pm 120$ & charcoal & $\mathrm{Ri}-52$ & $\begin{array}{l}\text { Veksler } 1989 ; \\
\text { Goriunova } 2003\end{array}$ \\
\hline $\begin{array}{l}\text { Zhertvennoe Mesto 101-go Kilometra, } \\
\text { Lena River }\end{array}$ & $5575 \pm 270$ & animal bone & SOAN-1682 & $\begin{array}{l}\text { Konopatsky } 1982 ; \\
\text { Orlova } 1995\end{array}$ \\
\hline
\end{tabular}

a Second date run on wood from the same grave No. 3 (excavations of 1972) is $6550 \pm 35$ BP (SOAN-790) (Konopatsky 1982: 72).

${ }^{\mathrm{b}}$ Humic acids extracted from soil were dated.

${ }^{\mathrm{c}}$ Birch bark ${ }^{14} \mathrm{C}$ date from the same grave is $4430 \pm 40 \mathrm{BP}$ (GIN-5598) (Goriunova 2003).

As for the reliability of ${ }^{14} \mathrm{C}$ dates from habitation sites, it is true that some are controversial. For example, the difference between $2{ }^{14} \mathrm{C}$ values for grave 3 (excavations of 1972) at the Shamanskii Mys is about $800 \mathrm{yr}$ (Table 2), and this make them less reliable. However, the validity of 2 other dates, from the Tudugu and "Zhertvennoe Mesto 101-go Kilometra" sites with ritual animal burials (Konopatsky 1982) — challenged due to the fact that they "...came from features of unknown or uncertain cultural association" (Weber (1995:135)—does not seem to be the issue in our case. It is obvious that these ritual structures were deliberately created by humans inhabiting the Cis-Baikal region at about 5880-5580 BP (Table 2), and the lack of exact cultural affiliation is not important for the question of the hiatus existence. 
I would agree that some problematic ${ }^{14} \mathrm{C}$ dates, such as one from the Shamanskii Mys ("Khuzhir" in Weber 1995:143) site, appear to still be trustworthy. This ${ }^{14} \mathrm{C}$ value of about $5990 \mathrm{BP}$ (Table 2) was considered less reliable due to the uncertainty in association with a particular cultural layer (Weber 1995:143). However, in the original report there is a clear indication that the date belongs to the upper cultural layer, depth of 0.35-0.40 m below the surface (Orlova 1995:218). This cultural component contains net-impressed pottery (Konopatsky 1982:32), which is quite characteristic for the Early Neolithic of Cis-Baikal (e.g. Goriunova 2003).

The analysis of ceramic assemblages associated with the selected "hiatus" sites (Table 2) shows that most of them have pottery with net-impressed design: Shamanskii Mys (Konopatsky 1982:71); Ulan-Khada (layer 10), Sagan-Zaba (layer 3), and Gorely Les (layer 5a) (Khlobystin 1996); and Ityrkhei (layers 5 and 6) and Sarminskii Mys (Goriunova 2003). Weber (1995:145) accepts that the net-impressed pottery manifests the beginning of the Neolithic, i.e. the Kitoi complex. Most probably, the ${ }^{14} \mathrm{C}$ dates for these sites of about $6000-5430 \mathrm{BP}$ reflect the existence of the Kitoi-Serovo continuum. It would appear that Kitoi-like populations with net-impressed pottery continued to survive in the Cis-Baikal region after $\sim 6100 \mathrm{BP}$, and some of the Serovo burials (e.g. Sarminskii Mys, grave $6, \sim 5500 \mathrm{BP}$ ) are older than other graves belonging to this complex, about 5200-3000 BP (e.g. Goriunova 2003). Thus, this evidence should also be considered to document the possibility of a continuation of human presence in the Cis-Baikal region after about 6100 BP. It should also be noted that one of the coauthors of Weber et al. (2006) disagreed with the discontinuity in the cultural chronology: Goriunova (2003:19) cited several ${ }^{14} \mathrm{C}$ dates from 5 sites of the Ol'khon Island area for the time interval of about 6000-5430 BP (see also Table 2).

In my opinion, the issue of possible environmental impact on the late Kitoi population (Weber et al. 2002) cannot be considered as one of the causes of the hiatus in human occupation. Data on vegetation and climate of the Cis-Baikal region for the Holocene (e.g. Bezrukova 1999; Horiuchi et al. 2000; Krivonogov et al. 2004) show that no significant changes occurred at about 8000-5000 BP; during this time, the environment was represented by conifer forests, with fluctuations in the spruce/ fir-pine ratio (Bezrukova 1999:114). In the broader scale of southern Siberia, there were no sharp climatic anomalies in the mid-Holocene compared with modern values (e.g. Monserud et al. 1998; Tarasov et al. 1998). The suggestion that "...not the Atlantic but the Subboreal period that saw the warmest temperatures during Holocene times in the Baikal region" (Weber et al. 2002:292) is not supported by primary evidence (e.g. Bezrukova 1999; Horiuchi et al. 2000; but see Karabanov et al. 2000). Under any conditions, the hiatus could have occurred before the beginning of the Subboreal period at about $4500 \mathrm{BP}$.

\section{CONSTRUCTION OF CIS-BAIKAL CULTURAL CHRONOLOGY: FACTS AND PROBLEMS}

After the publication of Weber et al. (2006), which summarized new results of AMS ${ }^{14} \mathrm{C}$ dating from burials in Cis-Baikal region, I would like to review the contribution of earlier Russian researchers. However, their original papers are often difficult to access due to the language barrier and their limited circulation. In the following, I list the "first-generation" conventional (i.e. liquid scintillation counting ${ }^{14} \mathrm{C}$ dates and their sources, which add primary data to the compendium of AMS values by Weber et al. (2006).

At the Lokomotiv burial ground, $7{ }^{14} \mathrm{C}$ values were obtained for the Kitoi cultural complex: grave 8 , $6870 \pm 70 \mathrm{BP}(\mathrm{GIN}-3329)$; grave 10, $6780 \pm 80 \mathrm{BP}(\mathrm{GIN}-330)$; grave 22, $6740 \pm 180 \mathrm{BP}$ (GIN$3331)$ and $6700 \pm 150 \mathrm{BP}(\mathrm{GIN}-3333)$; grave 23, $6750 \pm 60 \mathrm{BP}$ (GIN-4033); grave 24, $6830 \pm 80 \mathrm{BP}$ (GIN-4034); and grave 28, $6820 \pm 100$ BP (GIN-4035) (Mamonova and Sulerzhitsky 1989:22). These ${ }^{14} \mathrm{C}$ dates were later republished by Weber (1995:138). They are in most cases consistent with 
new AMS ${ }^{14} \mathrm{C}$ date series from the Lokomotiv site (Weber et al. 2006:129-38). For example, from grave 22, 3 dates are of about 6490-6660 BP; from grave 23, $6710 \pm 60 \mathrm{BP}$; from grave 24, 6 dates are of about 6440-6660 BP; and from grave 28, $6380 \pm 60 \mathrm{BP}$ (Weber et al. 2006:134-5). One ${ }^{14} \mathrm{C}$ value, $3445 \pm 75 \mathrm{BP}$ (SOAN-5168), was obtained for grave 5, which belongs to the Bronze or Early Iron Age complex (Turkin and Kharinskii 2004:150).

The Shamanka II cemetery was originally excavated by Turkin and Kharinskii (2004). They reported $4{ }^{14} \mathrm{C}$ dates from graves of the Glazkovo complex: burial 2, $3900 \pm 130 \mathrm{BP}$ (SOAN-3895); burial 3, $3890 \pm 45 \mathrm{BP}$ (SOAN-5165); burial 5, $3600 \pm 70 \mathrm{BP}$ (GIN-11229); and burial 9, $3520 \pm 60$ $\mathrm{BP}$ (GIN-11230). The AMS ${ }^{14} \mathrm{C}$ value from grave 9 obtained by Weber et al. (2006:140), $3600 \pm 50$ $\mathrm{BP}$, corresponds well to the GIN date. Two dates are associated with the cultural complex preceding the Glazkovo, perhaps the Kitoi one: $6600 \pm 180 \mathrm{BP}$ (GIN-10290) for grave 4; and $6090 \pm 130 \mathrm{BP}$ (GIN-10208) for grave 6 (Turkin and Kharinskii 2004:142).

For the Ust'-Ida I site, $1{ }^{14} \mathrm{C}$ date for grave 2, $4080 \pm 100 \mathrm{BP}$ (GIN-3881), was first published by Mamonova and Sulerzhitsky (1989) and repeated by Weber (1995:139). Later, Naumova et al. (1997) published 7 other ${ }^{14} \mathrm{C}$ dates for this site: burial 16, skeleton 1, $4640 \pm 50 \mathrm{BP}$ (GIN-7526); burial 16, skeleton 2, $4710 \pm 60 \mathrm{BP}$ (GIN-7525); burial 20, skeleton 1, $4890 \pm 100 \mathrm{BP}$ (GIN-6295); burial 26, skeleton 1, $5170 \pm 120 \mathrm{BP}$ (GIN-6290); burial 30, $4710 \pm 60 \mathrm{BP}$ (GIN-8006); burial 38, $4480 \pm 70 \mathrm{BP}(\mathrm{GIN}-7110)$; and burial $41,4480 \pm 70$ (GIN-7111). The AMS ${ }^{14} \mathrm{C}$ dates made by Weber et al. (2006:145-7) are the following: burial 16 (skeleton 1), $4710 \pm 70 \mathrm{BP}$; burial 20 (skeleton 1), $4540 \pm 60 \mathrm{BP}$; burial 26 (skeleton 1), $4740 \pm 70 \mathrm{BP}$; burial 30, $4860 \pm 110 \mathrm{BP}$; burial 38, $4730 \pm 60 \mathrm{BP}$; and burial 41, $4790 \pm 70 \mathrm{BP}$. Clearly, a difference between the 2 date series exists but is not very large, up to a few hundred ${ }^{14} \mathrm{C}$ years.

For the Khuzhir-Nuge XIV burial ground, $3{ }^{14} \mathrm{C}$ dates were originally obtained (see Weber et al. 2004:68): burial 2, $2900 \pm 200 \mathrm{BP}$ (GIN-7523); burial 4, $3860 \pm 100 \mathrm{BP}$ (GIN-7522); and burial 5, $3840 \pm 150 \mathrm{BP}(\mathrm{GIN}-8182)$. The AMS ${ }^{14} \mathrm{C}$ date for burial 5, $3910 \pm 60 \mathrm{BP}$ (Weber et al. 2006:150), is quite close to the GIN value.

The Khotoruk site originally produced $1{ }^{14} \mathrm{C}$ date for grave 2a: $7370 \pm 250 \mathrm{BP}$ (GIN-4107) (Mamonova and Sulerzhitsky 1989); this was later republished (Weber 1995:139). A new ${ }^{14} \mathrm{C}$ date for this individual, obtained by the AMS method, $7020 \pm 70 \mathrm{BP}$ (Weber et al. 2006:160), is in general agreement with the previous date, if we take into account the GIN-4107 value with $\pm 2 \sigma$.

For the Shamanskii Mys (or "Burkhan," "Ol'khon," and "Khuzhir" in other sources) cemetery, $2{ }^{14} \mathrm{C}$ dates were generated prior to research led by Weber: $4140 \pm 50$ BP (GIN-4099) for burial 2 excavated in 1972; and $3980 \pm 40 \mathrm{BP}$ (GIN-4098) for burial 2 excavated in 1973 (Mamonova and Sulerzhitsky 1989; see also Weber 1995:140). The new AMS dates for grave 2 (1972) are of about 4100-4150 BP; for burial 2 (1973), $3990 \pm 50 \mathrm{BP}$ (Weber et al. 2006:161). The new values are very close to the GIN dates.

For the Makrushina burial ground, Vetrov et al. (1995) reported $6{ }^{14} \mathrm{C}$ dates. Three of them are associated with the Kitoi cultural complex: burial 1, $7340 \pm 120$ BP (GIN-6288); burial 2, $6370 \pm 80$ BP (GIN-6816); and burial 9, $6520 \pm 50$ BP (GIN-7765). New AMS dates for the Makrushina are the following: grave 1, $6920 \pm 70 \mathrm{BP}$; and grave 2, $6720 \pm 70 \mathrm{BP}$ (Weber et al. 2006:161). The results are somehow different from the GIN ${ }^{14} \mathrm{C}$ values. As for the later Eneolithic (Vetrov et al. 1995:114) or Glazkovo (Weber et al. 2006:163) cultural component of the Makrushina, $3{ }^{14} \mathrm{C}$ dates were generated: burial 3, $4070 \pm 90$ BP (GIN-6831); burial 13, $4200 \pm 40$ BP (GIN-7766); and burial 14, $4310 \pm 40 \mathrm{BP}(\mathrm{GIN}-7767)$. 
This brief encounter with the first set of ${ }^{14} \mathrm{C}$ dates produced for the Cis-Baikal Neolithic and Bronze Age complexes, presented here especially for non-Russian speaking scholars, show that in most cases, new results (e.g. Weber et al. 2002, 2004, 2005, 2006) broadly confirmed the earlier conclusions (e.g. Konopatsky 1982:70-80; Mamonova and Sulerzhitsky 1989:28-31). Numerous AMS ${ }^{14} \mathrm{C}$ dates from burial grounds in the Cis-Baikal (in total 335 values; see Weber et al. 2006) do not change significantly the previous cultural chronology.

There are some other aspects of presentation of original data for the Cis-Baikal prehistoric cemeteries. Unfortunately, Weber et al. (2006) appear not to give sufficient credit, in my view, to the contribution of previous Russian researchers. For example, it is said: "A number of ${ }^{14} \mathrm{C}$ determinations were produced for the UID [Ust'-Ida I] cemetery in Russian laboratories; none, however, have been published thus far" (Weber et al. 2006:144). I would note in response that $1{ }^{14} \mathrm{C}$ value for Ust'-Ida I was published by Mamonova and Sulerzhitsky (1989:22, listed as Ust'-Uda; see above), and was already mentioned in other papers (e.g. Weber 1995:139; Weber et al. 2005:1487). In Naumova et al. (1997), 7 other ${ }^{14} \mathrm{C}$ dates for the Ust'-Ida I cemetery were also presented (see above).

In earlier publications of the ${ }^{14} \mathrm{C}$ date series from the Khuzhir-Nuge XIV cemetery, $3{ }^{14} \mathrm{C}$ values produced in Russia are listed (Weber et al. 2004:68); in a later article, 1 value, $2900 \pm 200$ BP (GIN7523), is not included (Weber et al. 2005:1484).

\section{CONCLUSION}

Based on the results obtained for the Neolithic assemblages from the Cis-Baikal region in southern Siberia and their ${ }^{14} \mathrm{C}$ ages, it seems that the "hiatus" at the transition from the Late Kitoi culture to the Early Isakovo/Serovo-Glazkovo complex may be an artifact of the limited sampling rather than a pattern in the archaeological chronology. Perhaps the Neolithic population size decreased in the Cis-Baikal to some extent at about $6100-5300 \mathrm{BP}$; this is reflected in the smaller number of ${ }^{14} \mathrm{C}$ dated sites and burial grounds compared with the previous "classical" Kitoi time period, about 7000-6100 BP. However, it is hard to imagine a complete or significant depopulation on the background of quite stable environment and food resources. I believe that the primary data testifies in favor of a continuous occupation and the existence of "mixed" Kitoi-Serovo assemblages.

\section{ACKNOWLEDGMENTS}

I am grateful to A W Weber for supplying me with some publications, and A J T Jull and an anonymous reviewer for editorial suggestions.

\section{REFERENCES}

Bezrukova EV. 1999. Paleogeografiya Pribaikalya $v$ Pozdnelednikovye i Golotsene [Paleogeography of the Cis-Baikal region in the Late Glacial and the Holocene]. Novosibirsk: Nauka Publishers. 128 p.

Goriunova OI. 2003. The Neolithic of the Ol'khon region (Lake Baikal). In: Weber A, McKenzie H, editors. Prehistoric Foragers of the Cis-Baikal, Siberia. Northern Hunter-Gatherers Research Series. Volume 1. Edmonton: Canadian Circumpolar Institute Press. p $15-35$.

Horiuchi K, Minoura K, Hoshino K, Oda T, Nakamura T, Kawai T. 2000. Palaeoenvironmental history of Lake Baikal during the last 23000 years. Palaeogeography, Palaeoclimatology, Palaeoecology 157(1-2):95-108.
Karabanov EB, Prokopenko AA, Williams DF, Khursevich GK. 2000. A new record of Holocene climate change from the bottom sediments of Lake Baikal. Palaeogeography, Palaeoclimatology, Palaeoecology 156(3-4):211-24.

Katzenberg MA, Weber AW. 1999. Stable isotope ecology and palaeodiet in the Lake Baikal region of Siberia. Journal of Archaeological Science 26(6):651-9.

Khlobystin LP. 1978. Vozrast i sootnoshenie neoliticheskikh kultur Vostochnoi Sibiri [The age and correlation of the Neolithic cultures of eastern Siberia]. In: Kruglikova IT, editor. Pamyatniki Epokhi Neolita. Kratkie Soobscheniya Instituta Arkheologii AN SSSR. Issue 153. Moscow: Nauka Publishers. 
p 93-9.

Khlobystin LP. 1996. Vostochnaya Sibir i Dalny Vostok [Eastern Siberia and the Far East]. In: Oshibkina SV, editor. Neolit Severnoi Evrazii. Moscow: Nauka Publishers. p 270-329.

Konopatsky AK. 1982. Drevnie Kultury Baikala (O. Olkhon) [Ancient cultures of the Lake Baikal (Olkhon Island)]. Novosibirsk: Nauka Publishers. 175 p.

Krivonogov SK, Takahara H, Kuzmin YV, Orlova LA, Jull AJT, Nakamura T, Miyoshi N, Kawamuro K, Bezrukova EV. 2004. Radiocarbon chronology of the Late Pleistocene-Holocene paleogeographic events in Lake Baikal region (Siberia). Radiocarbon 46(2): $745-54$.

Lam YM. 1994. Isotopic evidence for change in dietary patterns during the Baikal Neolithic. Current Anthropology 35(2): 185-90.

Mamonova NN, Sulerzhitsky LD. 1989. Opyt datirovaniya po ${ }^{14} \mathrm{C}$ pogrebenii Pribaikalya epokhi golotsena [The experience in ${ }^{14} \mathrm{C}$ dating of the Holocene burials in the Cis-Baikal region]. Sovetskaya Arkheologiya 32(1):19-32.

Michael HN. 1992. Siberia and the Soviet Far East. In: Ehrich RW, editor. Chronologies in Old World Archaeology. 3rd edition. Volume 2. Chicago: University of Chicago Press. p 405-17.

Monserud RA, Tchebakova NM, Denissenko OV. 1998 Reconstruction of the mid-Holocene palaeoclimate of Siberia using a bioclimatic vegetation model. Palaeogeography, Palaeoclimatilogy, Palaeoecology 139(12):15-36.

Naumova OY, Rychkov SY, Bazaliiskii VI, Mamonova NN, Sulerzhitskii LD, Rychkov YG. 1997. Molecular genetic characteristics of the Neolithic population of the Baikal region: RFLP of the ancient mtDNA from skeletal remains found in the Ust-Ida I burial ground. Russian Journal of Genetics 33(10):1215-21.

Orlova LA. 1995. Radiouglerodnoe datirovanie arkheologicheskikh pamyatnikov Sibiri i Dalnego Vostoka [Radiocarbon dating of archaeological sites from $\mathrm{Si}$ beria and the Far East]. In: Derevianko AP, Kholushkin YP, editors. Metody Estestvennykh Naukv Arkheologicheskikh Rekonstruktsiyakh. Chast 2. Novosibirsk: Institut Arkheologii i Etnografii SO RAN. p 207-32.

Orlova LA. 1998. Radiouglerodnoe datirovanie arkheologicheskikh pamyatnikov Sibiri i Dalnego Vostoka. II [Radiocarbon dating of archaeological sites from Siberia and the Far East. II]. In: Derevianko AP, Kholushkin YP, Rostovtsev PS, Voronin VT. Statistichesky Analiz Pozdnepaleoliticheskikh Kompleksov Severnoi Azii. Supplement. Novosibirsk: Izdatelstvo NII MIOO NGU. p 74-88.

Suslov SP. 1961. Physical Geography of Asiatic Russia. London: W.H. Freeman and Company. 594 p.

Tarasov PE, Webb III T, Andreev AA, Afanas'eva NB, Berezina NA, Bezusko NG, Blyakharchuk TA, Bo- likhovskaya NS, Cheddadi R, Chernavskaya MM, Chernova GM, Dorofeyuk NI, Dirksen VG, Elina GA, Filimonova LV, Glebov FZ, Guiot G, Gunova VS, Harrison SP, Jolly D, Khomutova VI, Kvavadze EV, Osipova IM, Panova NK, Prentice C, Saarse L, Sevastyanov DV, Volkova VS, Zernitskaya VP. 1998. Present-day and mid-Holocene biomes reconstructed from pollen and plant macrofossil data from the former Soviet Union and Mongolia. Journal of Biogeography 25(6):1029-53.

Turkin GV, Kharinskii AV. 2004. Mogilnik Shamanka II: $\mathrm{k}$ voprosu o khronologii i kulturnoi prinadlezhnosti pogrebalnykh kompleksov neolita-bronzovogo veka na yuzhnom Baikale [The Shamanka II cemetery: to the question of cultural affinity of the NeolithicBronze Age burial complexes in southern Baikal]. In: Kharinskii AV, editor. Izvestiia Laboratorii Drevnikh Tekhnologyi. Vypusk 2. Irkutsk: Izdatelstvo Irkutskogo Gosudarstvennogo Tekhnicheskogo Universiteta. p 124-58.

Veksler VS. 1989. Radiocarbon dates of Riga 2. Radiocarbon 31(1):47-54.

Vetrov VM, Berdnikova NE, Altukhov VV, Frolov AV. 1995. Makrushinsky mogilnik. Ranneneoliticheskii kompleks [The Makrushina burial ground. The Early Neolithic complex]. In: Vetrov VM, editor. Baikalskaya Sibir v Drevnosti. Irkutsk: Irkutsky Gosudarstvenny Universitet. p 112-32.

Weber A. 1994. Social evolution among Neolithic and Early Bronze Age foragers in the Lake Baikal region: new light on the old model. Arctic Anthropology 31(2):1-15.

Weber A. 1995. The Neolithic and Early Bronze Age of the Lake Baikal region, Siberia: a review of recent research. Journal of World Prehistory 9(1):99-165.

Weber AW, Bettinger R. 2003. Current goals of mid-Holocene hunter-gatherer archaeology in the Lake Baikal region. In: Weber A, McKenzie H, editors. Prehistoric Foragers of the Cis-Baikal, Siberia. Northern HunterGatherers Research Series. Volume 1. Edmonton: Canadian Circumpolar Institute Press. p 1-14.

Weber A, McKenzie H, editors. 2003. Prehistoric Foragers of the Cis-Baikal, Siberia. Northern Hunter-Gatherers Research Series. Volume 1. Edmonton: Canadian Circumpolar Institute Press. 215 p.

Weber A, Goriunova OI, Konopatskii AK. 1993. Prehistoric seal hunting on Lake Baikal: methodology and preliminary results of the analysis of canine sections. Journal of Archaeological Science 20(6):629-44.

Weber A, Link DW, Goriunova OI, Konopatskii AK. 1998. Patterns of prehistoric procurement of seal at Lake Baikal: a zooarchaeological contribution to the study of past foraging economies in Siberia. Journal of Archaeological Science 25(3):215-27.

Weber AW, Link DW, Katzenberg MA. 2002. Huntergatherer culture change and continuity in the Middle Holocene of the Cis-Baikal, Siberia. Journal of An- 
thropological Archaeology 21(2):230-99.

Weber AW, Beukens RP, Goriunova OI. 2004. Radiocarbon dating of the Bronze Age cemetery Khuzhir Nuge XIV on Lake Baikal. Archaeology, Ethnology and Anthropology of Eurasia 5(4)[No. 20]:64-72.

Weber A, McKenzie HG, Beukens R, Goriunova OI. 2005. Evaluation of radiocarbon dates from the Mid- dle Holocene hunter-gatherer cemetery Khuzhir-Nuge XIV, Lake Baikal, Siberia. Journal of Archaeological Science 32(10):1481-500.

Weber AW, Beukens RP, Bazaliiskii VI, Goriunova OI, Savel'ev NA. 2006. Radiocarbon dates from Neolithic and Bronze Age hunter-gatherer cemeteries in the CisBaikal region of Siberia. Radiocarbon 48(1):127-66. 